\title{
IN SITU METHANE ENRICHMENT IN METHANOGENIC ENERGY CROP DIGESTERS
}

\author{
Brian K. Richards, Frederick G. Herndon, * William J. Jewell, Robert J. Cummings and \\ Thomas E. WhITE* \\ Department of Agricultural and Biological Engineering, Riley-Robb Hall, Cornell University, Ithaca, \\ New York 14853-5701, U.S.A.
}

(Received 23 September 1993; revised received 24 January 1994; accepted 28 January 1994)

\begin{abstract}
A simple in situ technique to enrich digester offgas, which normally contains $30-50 \%$ carbon dioxide $\left(\mathrm{CO}_{2}\right)$ by volume, was developed to take advantage of the differing solubilities of $\mathrm{CO}_{2}$ and methane $\left(\mathrm{CH}_{4}\right)$. Dissolved $\mathrm{CO}_{2}$ was removed from the digester in a recycled leachate stream and gas stripped in an external stripper. Bench-scale systems easily enriched the remaining digester offgas to over $95 \% \mathrm{CH}_{4}$, and $\mathrm{CH}_{4}$ purities in excess of $98 \%$ were achieved. Quantitative evaluation of system variables defined the effects of leachate recycle rates and alkalinity on the resulting offgas methane contents. Offgas $\mathrm{CH}_{4}$ contents correlated well with the ratio of $\mathrm{CO}_{2}$ transport capacity to $\mathrm{CO}_{2}$ production. This ratio was termed the alkalinity $/ \mathrm{CO}_{2}$ ratio, a variable representing the cumulative effects of leachate recycle, leachate alkalinity and digester gas production. Operation at alkalinities of 2 and $4 \mathrm{~g} \mathrm{l}^{-1}$ (as $\mathrm{CaCO}_{3}$ ) was more effective than $8 \mathrm{~g}^{-1}$ for the specific mode of operation used in this study, as elevated alkalinities required extensive lag times between feeding and initiation of stripping, resulting in blow-by of $\mathrm{CO}_{2}$ into the digester offgas, lowering the offgas $\mathrm{CH}_{4}$ content. Excessively high recycle rates led to digester $\mathrm{pH}$ levels above 8.1, resulting in volatile fatty acid accumulation and lowered $\mathrm{CH}_{4}$ production rates.
\end{abstract}

Keywords-Anaerobic digestion; substitute natural gas; methane; gas quality; energy crops; biogas; enrichment.

\section{INTRODUCTION}

Much progress has been made in the development of technology for the cost-effective production of methane $\left(\mathrm{CH}_{4}\right)$ as a substitute natural gas via fermentation of energy crops. Systems analyses have been conducted to determine the key areas where improvements in economics are necessary. ${ }^{1,2}$ One of the most significant cost factors is the purification of digester offgas (biogas) to meet pipeline quality $\left(95 \% \mathrm{CH}_{4}\right)$. Biogas generally contains $50-60 \%$ $\mathrm{CH}_{4}$, with the balance being carbon dioxide $\left(\mathrm{CO}_{2}\right)$ and small quantities of hydrogen sulphide. In place of costly gas treatment processes (physical-chemical processes such as a molecular sieve are estimated to cost $\$ 1.50-2.50$ per GJ), in situ purification has been proposed, which takes advantage of the differential solubility of $\mathrm{CO}_{2}$ and $\mathrm{CH}_{4}$.

Ferguson et al..$^{3}$ proposed a system whereby $\mathrm{CO}_{2}$ was removed from a recycle stream by air stripping. The goal was not methane enrichment

*Current address: CIBA-GEIGY Corporation, P.O. Box 18300 , Greensboro, NC, 27419-8300, USA. but stabilization of digester $\mathrm{pH}$ to allow stable digestion of acidic waste streams.

A concept first described by Hayes and Isaacson $^{4}$ employs phase separation, with a firstphase leaching bed at a gauge pressure of $0 \mathrm{~atm}$ and a temperature of $35^{\circ} \mathrm{C}$, and a second-phase packed bed at a pressure of $2 \mathrm{~atm}$. The combination of low pressure and low $\mathrm{pH}$ in the acetogenic first-phase reactor decreases $\mathrm{CO}_{2}$ solubility, encouraging $\mathrm{CO}_{2}$ offgassing in this stage. Conversely, the high $\mathrm{pH}$ and increased pressure of the methanogenic phase result in high $\mathrm{CO}_{2}$ solubility and low $\mathrm{CO}_{2}$ offgassing, resulting in higher $\mathrm{CH}_{4}$ contents. Their model predicted methanogenic phase $\mathrm{CH}_{4}$ contents of $92 \%$, assuming an alkalinity of $500 \mathrm{mg} \mathrm{l}^{-1}$. Hayes et al. ${ }^{5}$ subsequently showed that the creation of such a separated phase digestion, differential pressure system combined with liquid recycle resulted in $\mathrm{CH}_{4}$ contents of up to $93 \%$.

Experiments described in this paper were begun in $1987^{6-8}$ to test and optimize a simpler in situ process. This process was based solely on the differential solubilities of $\mathrm{CH}_{4}$ and $\mathrm{CO}_{2}$ under ambient pressure throughout the system, 
and with no attempt to separate acidogenic and methanogenic fermentation phases. For water at $55^{\circ} \mathrm{C}$ at ambient pressure, the saturation solubility of $\mathrm{CH}_{4}$ will equal $0.16 \%$ of the saturation solubility of $\mathrm{CO}_{2}$. The hypothesized process used continuously recycled leachate from a semicontinuously fed and mixed reactor (SCFMR) through an external gas-stripping chamber. The stripper was operated using a sweep gas to decrease the partial pressure of $\mathrm{CO}_{2}$ in the liquid, thus stripping the $\mathrm{CO}_{2}$ from the liquid (with correspondingly negligible $\mathrm{CH}_{4}$ losses, as so little is in solution). This removal of $\mathrm{CO}_{2}$ in the stripper resulted in high $\mathrm{CH}_{4}$ purities in the SCFMR offgas. Removal of $\mathrm{CO}_{2}$ would also increase $\mathrm{pH}$ in the liquid and, due to recycle, in the SCFMR as well.

The $\mathrm{CH}_{4}$ content of digester offgas in such a system will be affected by variables such as $\mathrm{pH}$, alkalinity, gas production rate and recycle flow rate. In order to model and optimize the operation, an understanding of the relationships between key variables and digester performance is critical. The objective of this study was to investigate key variables affecting methane enrichment in order to identify critical operating parameters between which a digester can be successfully operated and to observe the effects of operation with those parameters.

\section{EXPERIMENTAL}

\subsection{Reactor system}

The system (Fig. 1) was designed to recycle $\mathrm{CO}_{2}$-rich leachate from the digester to an external gas-stripping column. The digester used consisted of a 121 clear Plexiglas ${ }^{\mathrm{TM}}$ cylinder (15 cm internal diameter (ID)), with net digester contents of 8-10 kg. Digester offgas was accu-

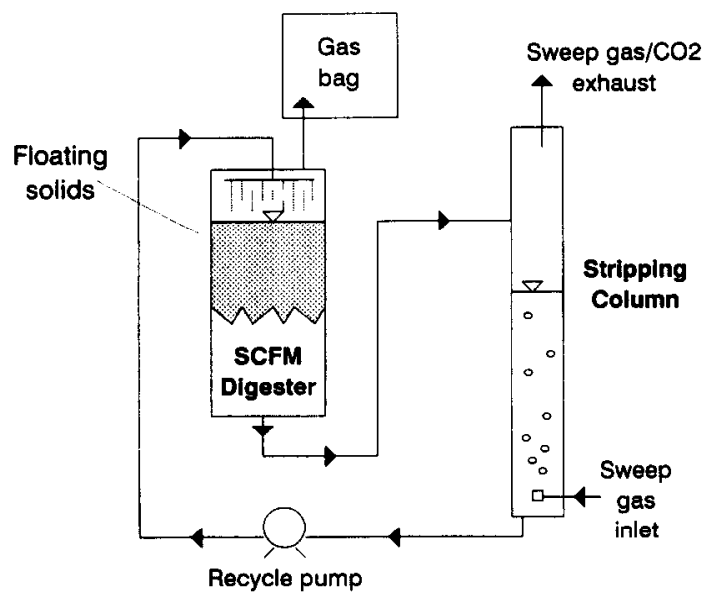

Fig. 1. Methane enrichment system configuration: constant recycle. mulated in a 601 Tedlar $^{\mathrm{rM}}$ gas bag. A screened intake manifold in the bottom of the digester allowed liquid to drain from the digester and flow into the gas stripper. The stripper consisted of a $1.5 \mathrm{~m}$ tall column $(10 \mathrm{~cm}$ ID) with a liquid volume of 21 . Leachate was pumped from the base of the stripper back to the top of the digester using a peristaltic pump. Sweep gas (compressed nitrogen) was first humidified by bubbling through water and then introduced into the bottom of the stripper through a stone gas diffuser at a rate of $0.71 \mathrm{~min}$. The open top of the stripper allowed the sweep gas and $\mathrm{CO}_{2}$ to be vented to the atmosphere. Stripper liquid retention times were inversely proportional to recycle rates, varying from nearly $10 \mathrm{~h}\left(0.51 \mathrm{~kg}^{-1} \mathrm{day}^{-1}\right.$ recycle rate $)$ to $1.1 \mathrm{~h}\left(41 \mathrm{~kg}^{-1} \mathrm{day}^{-1}\right.$ recycle rate $)$.

For conditions in which the recycle was $\mathrm{pH}$ controlled, a pH controller (Cole-Parmer Model 5656-00) and an additional recycle loop were added (Fig. 2), which enabled cycling of leachate from the bottom to the top of the digester. Whenever leachate $\mathrm{pH}$ exceeded a $\mathrm{pH}$ setpoint, recycle to the stripper was discontinued and the added internal recycle loop was activated.

\subsection{Substrate}

Sorghum, a candidate 'energy crop', was the feedstock used throughout the study. Analysis and composition are given in detail elsewhere. ${ }^{7-9}$ Whole plants (including grain) were field chopped and ensiled. Prior to use, they were rapidly air dried to prevent spoilage, and were hammer milled to fracture seeds. The sorghum

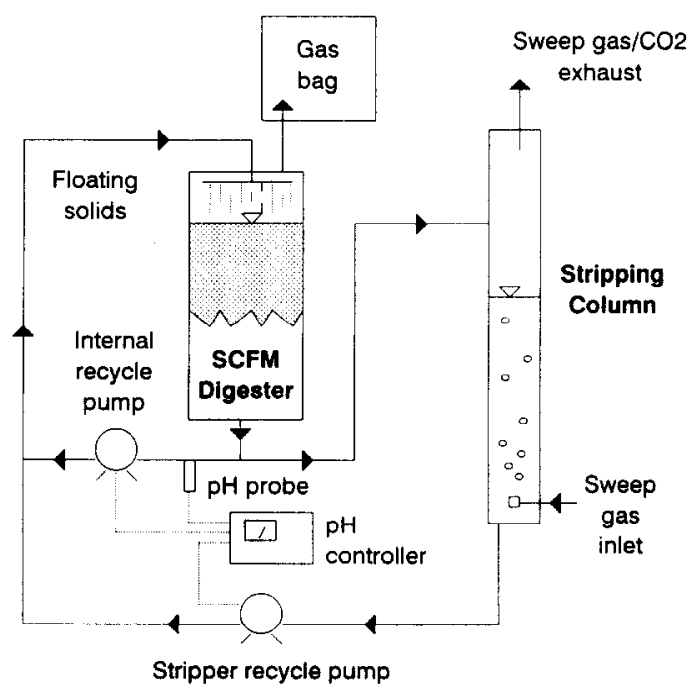

Fig. 2. Methane enrichment system configuration: $\mathrm{pH}$ controlled recycle. 
had a significant soluble organic fraction that was rapidly biodegradable, which characteristically led to rapid gas production rates following feeding, with rates peaking approximately 6 hours after start up. ${ }^{9}$ Typical offgas contents from digestion of this crop were $52-56 \% \mathrm{CH}_{4}$, with volatile solids (VS) removals commonly in excess of $70 \%$.

\subsection{Conditions examined}

A range of leachate alkalinities and recycle rates as well as digester loading rates and total solids concentrations were examined. Leachate total alkalinities examined were 2,4 and $8 \mathrm{~g}^{-1}$ as $\mathrm{CaCO}_{3}$. Conditions ME-4 to ME-14 in 1988 were operated at a loading rate of $2 \mathrm{gVS} \mathrm{kg}^{-1} \mathrm{day}^{-1}$ at a controlled emluent solids concentration of $9 \%$ total solids (TS). Solids contents were lowered to $5-6 \%$ TS for conditions ME-15 to ME-23, with the loading rate lowered to $1.25 \mathrm{gVS} \mathrm{kg}^{-1} \mathrm{day}^{-1}$. During $\mathrm{pH}$ controlled operation (ME-25 to ME-31) the loading rate was $4 \mathrm{gVS} \mathrm{kg}^{-1} \mathrm{day}^{-1}$ at $8 \%$ TS. Digester alkalinities were controlled by dilution (replacing a portion of the leachate with water to lower alkalinity) or by $\mathrm{K}_{2} \mathrm{CO}_{3}$ additions (to raise alkalinity). All digesters were allowed to equilibrate for as long as required to adjust to changes in control variables between conditions.

The digester was operated as a SCFMR, fed from three to seven times per week. Liquid addition rates (and therefore digester retention times) were varied as needed to maintain constant digester solids contents at the various VS loading rates. At each feeding, the digester was thoroughly hand mixed before effluent removal and again after addition of feed and water. After each feeding, a lag time of several hours (up to $6 \mathrm{~h}$ for $8 \mathrm{~g} \mathrm{l}^{-1}$ alkalinity conditions) was required for the digester solids to form a floating layer before recycle could be reinitiated.

Concurrent SCFMR control digesters were operated at similar loading rates and effluent TS concentrations. Correspondence of control reactors to $\mathrm{CH}_{4}$ enhancement conditions was as follows: control C-1: ME-4 to 14, control C-3: ME-15 to 23, control C-6: ME-25, control C-7: ME-27 to 30, control C-8: ME 31 .

\subsection{Analytical methods}

Accumulated digester offgas volumes were measured with a wet-gas meter. Gas volumes were standardized as dry gas at $0^{\circ} \mathrm{C}$ and $1 \mathrm{~atm} .^{10}$ Loading and gas production rates were expressed on a digester wet mass basis. ${ }^{10} \mathrm{CH}_{4}$ and $\mathrm{CO}_{2}$ contents of the digester offgas were deter- mined with a Gow-Mac Series 550 thermal conductivity detector equipped with a $1.8 \mathrm{~m}$ stainless steel $6.35 \mathrm{~mm}$ ID column packed with 60/80 Porapak Q, with helium carrier gas. Stripper offgases were not analysed for several reasons. First, offgas concentrations would vary during a given feeding cycle due to the variable rates of gas production typically resulting from semicontinuous feedings, ${ }^{9}$ requiring either constant on-line gas analysis or that all offgas for a given cycle be accumulated, mixed and sampled, with neither being feasible within the scope of the present study. Secondly, the offgas concentrations of stripped gases, particularly $\mathrm{CH}_{4}$, would have been at or below the detection limits of this study's equipment. Thus, removal of $\mathrm{CO}_{2}$ and $\mathrm{CH}_{4}$ in the stripper were not directly quantified.

Volatile fatty acid (VFA) analysis was performed with a Gow-Mac 740-P flame ionization detector, equipped with a Supelco $15 \mathrm{~m}$ $\mathrm{Nukol}^{\mathrm{TM}}$ capillary column. VFA samples were extracted from the effluent material by diluting with water, acidifying with $\mathrm{H}_{3} \mathrm{PO}_{4}$ to below $\mathrm{pH}$ 2 , agitating for $10 \mathrm{~min}$, and centrifuging and filtering. Total alkalinity was determined by potentiometric titrations with $0.15 \mathrm{~N} \mathrm{H}_{2} \mathrm{SO}_{4}$ to a $\mathrm{pH} 4.3$ endpoint.

Leachate recycle rates were expressed in three ways. The first was based on the volume of leachate recycled per unit digester wet mass per day (LRR, $1 \mathrm{~kg}^{-1} \mathrm{day}^{-1}$ ). The second basis of expression was found by dividing the rate of leachate recycle (LRR) by the rate of digester $\mathrm{CO}_{2}$ production, yielding a 'recycle ratio' (1 leachate $1^{-1} \mathrm{CO}_{2}$ produced). The third basis was calculated by multiplying the recycle ratio by the leachate alkalinity concentration, yielding a ratio of relative $\mathrm{CO}_{2}$ transport capacity to the production rate, termed the 'alkalinity/ $\mathrm{CO}_{2}$ ratio":

$$
A C R=L R R * T A l k / V_{C i},
$$

where: $\mathrm{ACR}=$ alkalinity $/ \mathrm{CO}_{2}$ ratio (g alkalinity recycled $1^{-1} \quad \mathrm{CO}_{2}$ produced); $\mathrm{LRR}=$ leachate recycle rate $\left(\mathrm{kg}^{-1} \mathrm{day}^{-1}\right)$; TAlk = leachate total alkalinity $\left(\mathrm{g} \mathrm{CaCO}_{3}\right.$ equivalent $\left.\mathrm{l}^{-1}\right)$; and $\mathrm{V}_{\mathrm{Ci}}=$ calculated initial $\mathrm{CO}_{2}$ production rate $\left(1 \mathrm{~kg}^{-1} \mathrm{day}^{-1}\right)$.

Initial digester $\mathrm{CO}_{2}$ production rates $\left(\mathrm{V}_{\mathrm{Ci}}\right)$ were calculated from measured $\mathrm{CH}_{4}$ production rates and associated control digester mean $\mathrm{CH}_{4}$ contents:

$$
\mathrm{V}_{\mathrm{Ci}}=\mathrm{V}_{\mathrm{Mo}_{\mathrm{o}}}\left(100-\mathrm{M}_{\mathrm{i}}\right) / \mathrm{M}_{\mathrm{i}}
$$




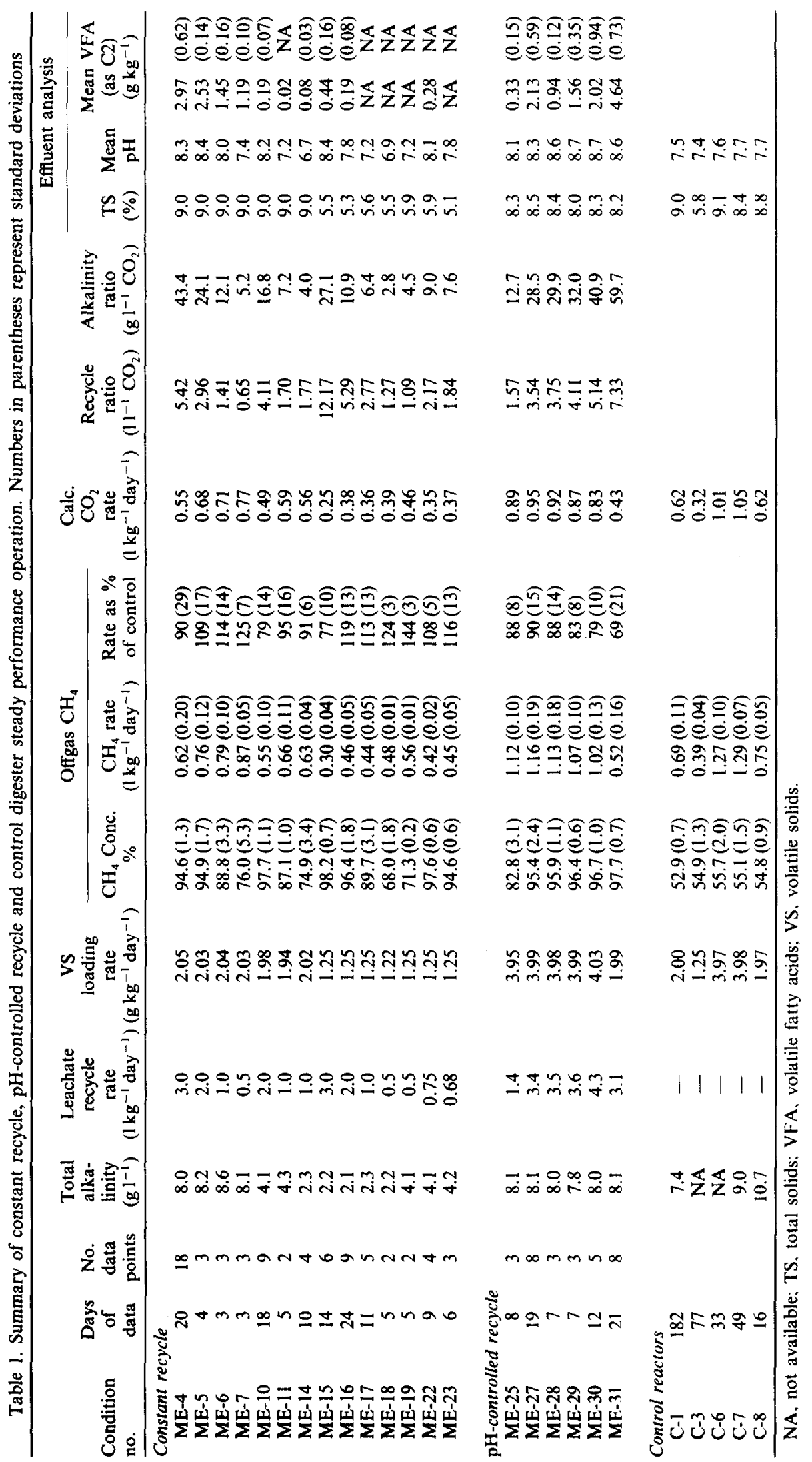


where: $\mathrm{V}_{\mathrm{Ci}}=$ calculated initial $\mathrm{CO}_{2}$ production rate $\left(\mathbf{~ k g}^{-1}\right.$ day $\left.^{-1}\right)$; $\mathrm{V}_{\mathrm{Mo}}=$ measured offgas $\mathrm{CH}_{4}$ production rate $\left(1 \mathrm{~kg}^{-1} \mathrm{day}^{-1}\right)$; and $\mathrm{M}_{\mathrm{i}}=$ measured control digester $\mathrm{CH}_{4}$ content $(\% \mathrm{CH})$.

\section{RESULTS}

Results are summarized in Table 1. Cumulative days of steady performance data and the number of actual data points (feeding intervals) represented are given for each condition. The data shown characterize the condition once stable performance was achieved. Variability of several key indices of operation $\left(\mathrm{CH}_{4}\right.$ content and production rate, $\mathrm{CH}_{4}$ production rate as percent of control rate, and VFA content) is indicated by standard deviations in parentheses.

The use of semicontinuous feeding in order to provide constant gas production rates (i.e. as opposed to batch digestion) led to operational problems such as plugging of recycle lines, particularly at higher recycle rates. This resulted in several conditions being discarded due to unsteady physical operation (data not shown).

The use of the recycle ratio basis (I leachate recycled $1^{-1} \mathrm{CO}_{2}$ produced) for expressing recycle rates served well to remove VS loading and gas production rates as separate variables. As can be seen in Fig. 3, offgas $\mathrm{CH}_{4}$ contents for 2, 4 and $8 \mathrm{~g} \mathrm{l}^{-1}$ alkalinity fell into distinct curves. As would be expected, recycling requirements were lower for $4 \mathrm{~g} \mathrm{l}^{-1}$ alkalinity conditions than for those at $2 \mathrm{~g}^{-1}$ due to the higher $\mathrm{CO}_{2}$-carrying capacity resulting from higher alkalinity. $\mathrm{Re}$ cycle ratios necessary to achieve $95 \%$ offgas $\mathrm{CH}_{4}$ contents were approximately 4.5 and $1.811^{-1}$ $\mathrm{CO}_{2}$ at alkalinities of 2 and $4 \mathrm{~g}^{-1}$, respectively.

An expected additional enhancement of offgas $\mathrm{CH}_{4}$ resulting from operating at $8 \mathrm{~g} \mathrm{l}^{-1}$ alkalinity was realized only at low rates of recycle, i.e. under $1.5 \mathrm{l}^{-1} \mathrm{CO}_{2}$. However, this enhancement of performance did not hold at higher recycle rates due to physical problems. As noted earlier, the formation of the layer of floating solids was a necessary prerequisite to initiation of recycle after feeding. At $8 \mathrm{~g}^{-1}$ alkalinity, the required delay was unusually long, averaging $6 \mathrm{~h}$ in several conditions, as opposed to $2-3 \mathrm{~h}$ at lower alkalinities. The reason why float layer formation was so slow at $8 \mathrm{~g} \mathrm{l}^{-1}$ alkalinity is not known. During this delay, an irretrievable 'blow-by' of $\mathrm{CO}_{2}$ from the digester into the offgas occurred, thereby limiting the cumulative gas-stripping ability of the system. This limitation occurred in both the continuous and $\mathrm{pH}$-controlled conditions.

The use of the 'alkalinity $/ \mathrm{CO}_{2}$ ratio', the ratio of relative $\mathrm{CO}_{2}$ transport capacity to the production rate, expressed as $\mathrm{g}$ alkalinity recycled $1^{\prime} \mathrm{CO}_{2}$ produced, allowed the collective effects of leachate recycle rate, leachate alkalinity and digester gas production rate to be expressed in

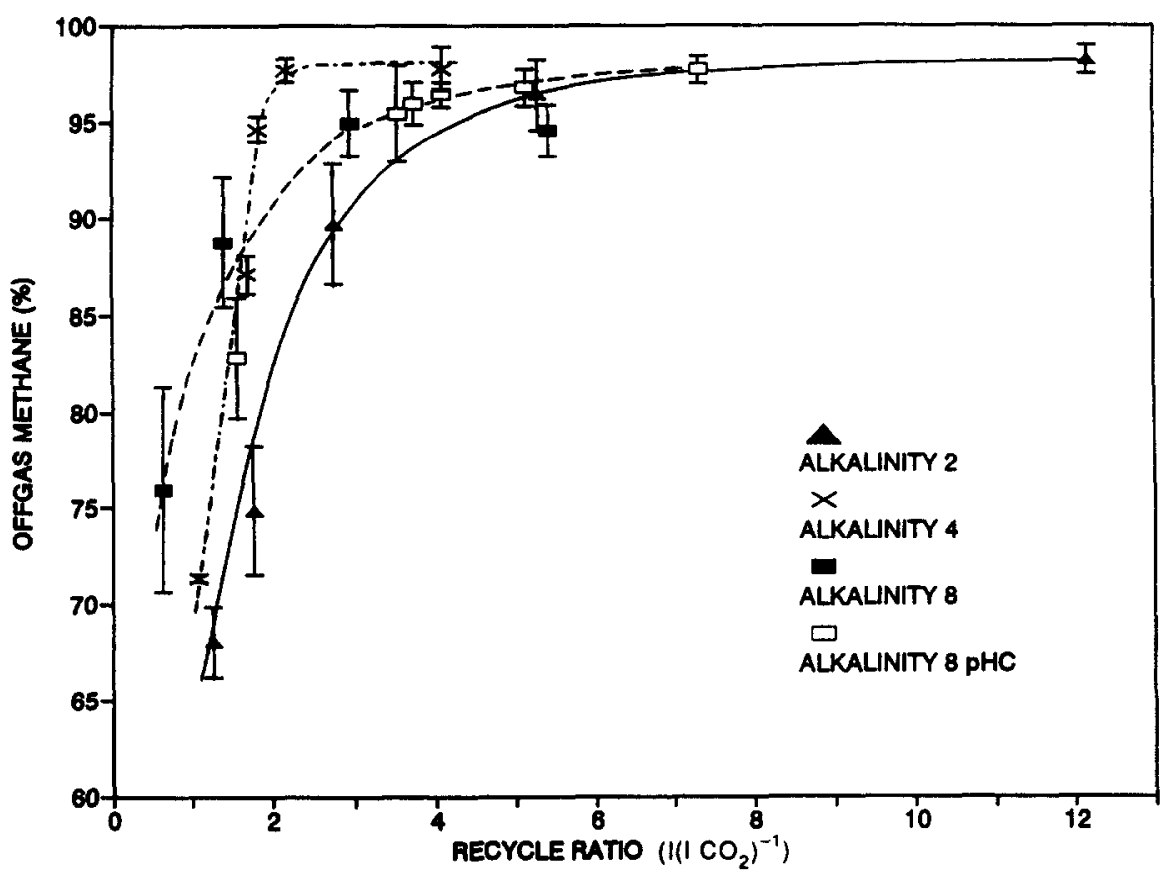

Fig. 3. Effect of recycle ratio (1 leachate recycled $1^{-1} \mathrm{CO}_{2}$ produced) on offgas $\mathrm{CH}_{4}$ concentration at alkalinities of 2,4 and $8 \mathrm{~g} \mathrm{l}^{-1}$. 'pHC' refers to $\mathrm{pH}$-controlled conditions. Error bars represent standard deviations. 
a single variable. There was excellent agreement between the offgas $\mathrm{CH}_{4}$ contents from 2 and $4 \mathrm{~g} \mathrm{I}^{-1}$ alkalinity conditions when recycle rates were expressed on this basis (Fig. 4). An alkalinity $/ \mathrm{CO}_{2}$ ratio of approximately $7.5 \mathrm{~g}$ alkalinity $\mathrm{I}^{-1} \mathrm{CO}_{2}$ was required to reach $\mathrm{CH}_{4}$ contents of $95 \%$. As before, the physical limitations encountered in $8 \mathrm{~g} \mathrm{t}^{-1}$ alkalinity operating conditions led to less effective $\mathrm{CH}_{4}$ enhancement, with alkalinity $/ \mathrm{CO}_{2}$ ratios of over 20 required to reach $95 \% \mathrm{CH}_{4}$.

The correlation between the degree of gas stripping and digester $\mathrm{pH}$ is shown in Fig. 5. At low levels of recycle (alkalinity $/ \mathrm{CO}_{2}$ ratios of less than $7.5 \mathrm{~g} \mathrm{l}^{-1} \mathrm{CO}_{2}$ ), $\mathrm{pH}$ values were comparable to control digesters. Exceptions to this were the $2 \mathrm{~g} \mathrm{l}^{-1}$ alkalinity conditions at the two lowest recycle rates, which had pHs of under 7.0. For these conditions there was substantial $\mathrm{CO}_{2}$ remaining in the system (offgas $\mathrm{CH}_{4}$ contents were under $75 \%$ ), with relatively little alkalinity to counteract it. For all alkalinity concentrations, alkalinity $/ \mathrm{CO}_{2}$ ratios of greater than approximately $12 \mathrm{~g} \mathrm{l}^{-1} \mathrm{CO}_{2}$ resulted in mean $\mathrm{pH}$ values in excess of 8.0 , with $\mathrm{pHs}$ as high as 8.7 observed at high alkalinity $/ \mathrm{CO}_{2}$ ratios.

As shown in Fig. 6, pH values much in excess of 8.1 correlated with depressed $\mathrm{CH}_{4}$ production rates. To compensate for varied loading rates, $\mathrm{CH}_{4}$ production rates were expressed as a percentage of associated control digester rates. $\mathrm{CH}_{4}$ production rates for conditions below $\mathrm{pH} 8.1$ appeared to be somewhat enhanced over control rates, possibly due to a beneficial mixing effect afforded by moderate recycle rates. Associated with the reduction in $\mathrm{CH}_{4}$ production rates at high $\mathrm{pHs}$ was the fact that VFA concentrations tended to be higher and more variable (Fig. 7). This effect of $\mathrm{pH}$ on $\mathrm{CH}_{4}$ production and VFA concentrations was reflected in additional conditions (not presented here because they were unstable), where operation at high recycle rates led to offgas $\mathrm{CH}_{4}$ contents of nearly $100 \%$, but $\mathrm{CH}_{4}$ production rates dropped rapidly and VFA concentrations increased as the $\mathrm{pH}$ approached 9.

\section{DISCUSSION}

Operation of a simple ambient pressure digester system utilizing leachate recycle to an external stripper can achieve high-quality $\mathrm{CH}_{4}$. However, the particular digester configuration chosen for examination in this study had a number of limitations. For practical purposes, the application for SCFMR or CSTR (continuously stirred) digesters is limited to relatively low-solids systems, with solids that are easily separated via flotation from the leachate stream. Due to liquid flow limitations, $\mathrm{CH}_{4}$ production rates are limited to the vicinity of $11 \mathrm{~kg}^{-1} \mathrm{day}^{-1}$. Although not investigated in this study because of the desire to maintain steady gas production

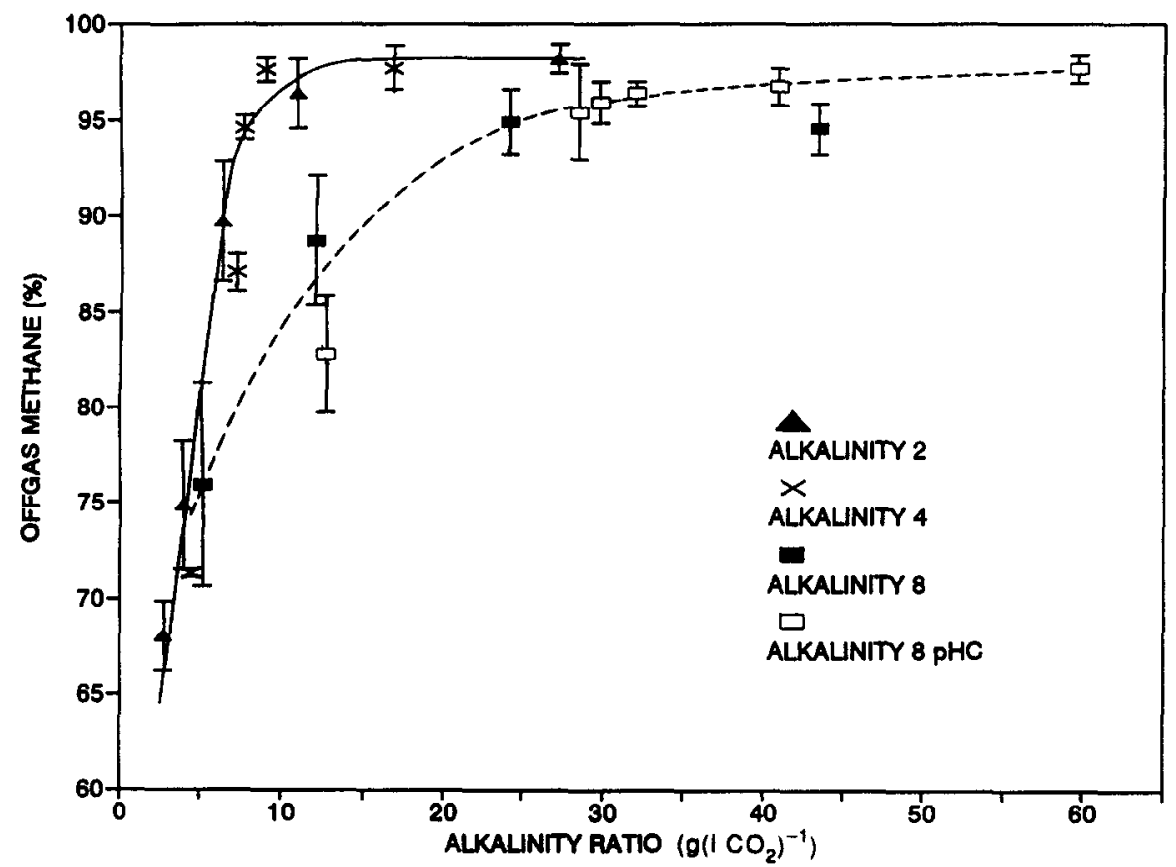

Fig. 4. Effect of alkalinity/ $\mathrm{CO}_{2}$ ratio (g alkalinity recycled $\mathrm{l}^{-1} \mathrm{CO}_{2}$ produced) on offgas $\mathrm{CH}_{4}$ concentration. 


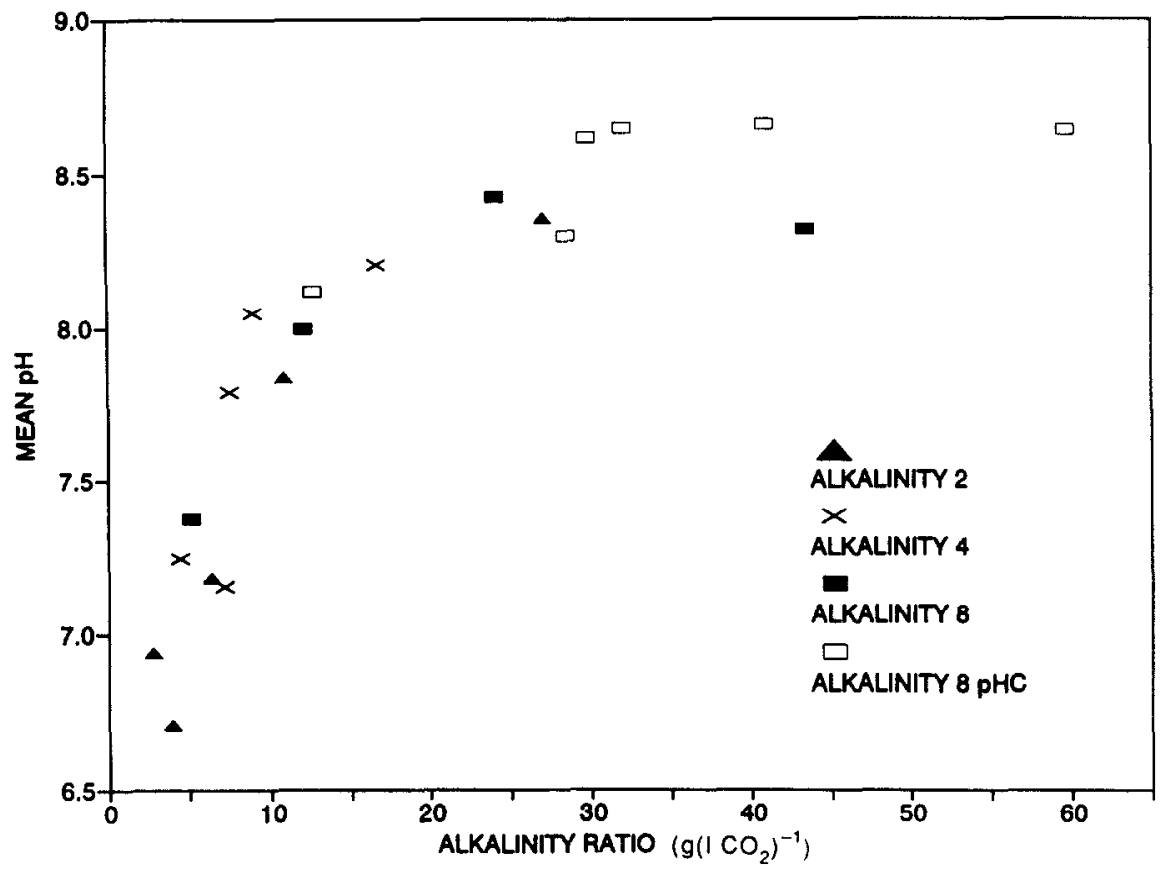

Fig. 5. Effect of alkalinity $/ \mathrm{CO}_{2}$ ratio (g alkalinity recycled $1^{-1} \mathrm{CO}_{2}$ produced) on mean digester $\mathrm{pH}$

rates, the use of leachate recycle in other types of digesters such as packed beds has been suggested.

However, irrespective of the digester configuration, the need to balance maximization of $\mathrm{CH}_{4}$ content with $\mathrm{pH}$ constraints is evident. For the conditions at alkalinities of $2-4 \mathrm{~g} \mathrm{l}^{-1}$, it appears that the optimum recycle rate (expressed as alkalinity $/ \mathrm{CO}_{2}$ ratio) was $10 \mathrm{gl}^{-1}$ $\mathrm{CO}_{2}$, which resulted in offgas $\mathrm{CH}_{4}$ contents of over $95 \% \mathrm{CH}_{4}$ and digester $\mathrm{pH}$ values between 7.8 and 8.1. These $\mathrm{pH}$ values were low enough to avoid reduction of $\mathrm{CH}_{4}$ production and VFA accumulations. While a $\mathrm{pH}$ of 7.5 has been suggested as the normal upper limit for anaerobic digestion, ${ }^{11} \mathrm{pH}$ values up to 8.1 were tolerated under these systems with minimal reduction in conversion efficiencies. Note that even in this $\mathrm{pH}$ range, care must be taken to ensure that ammonia nitrogen contents do not

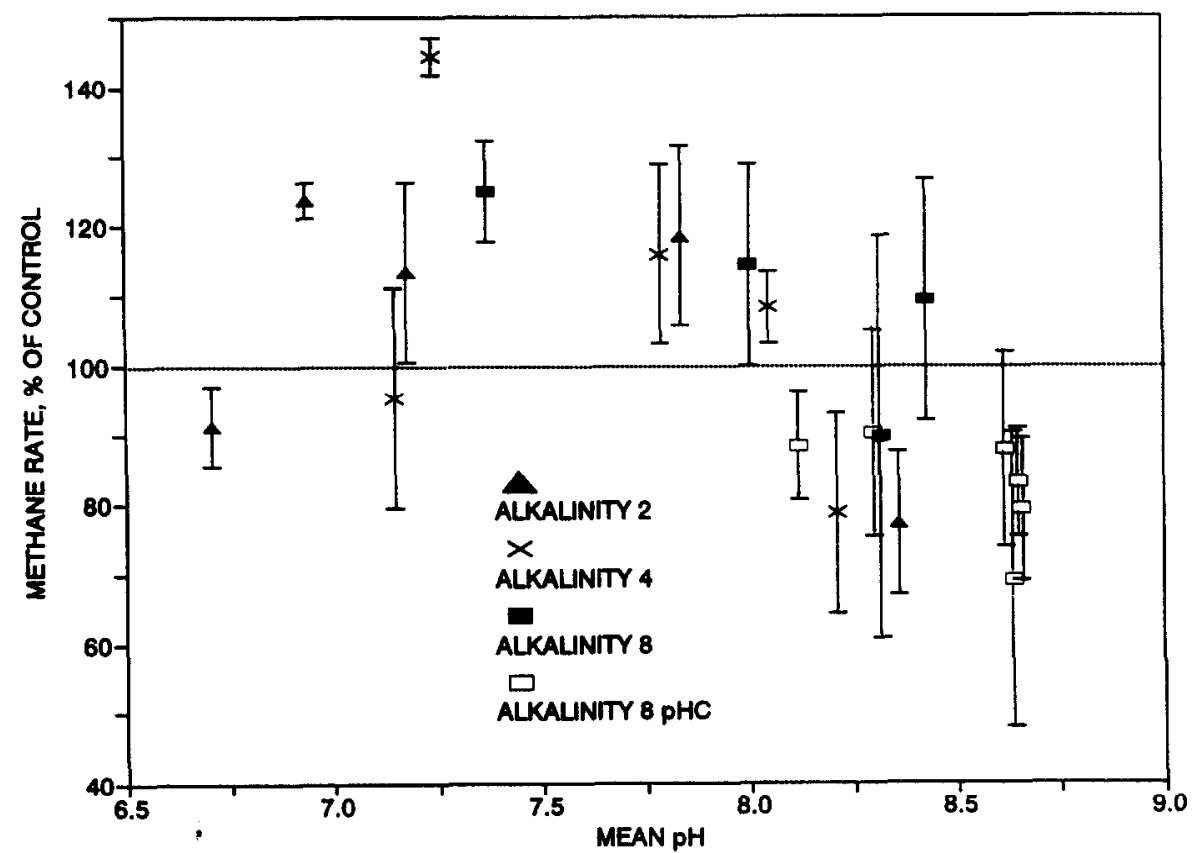

Fig. 6. Relationship of the mean digester $\mathrm{pH}$ to relative $\mathrm{CH}_{4}$ production rate (as \% of control $\mathrm{CH}_{4}$ production rate). 


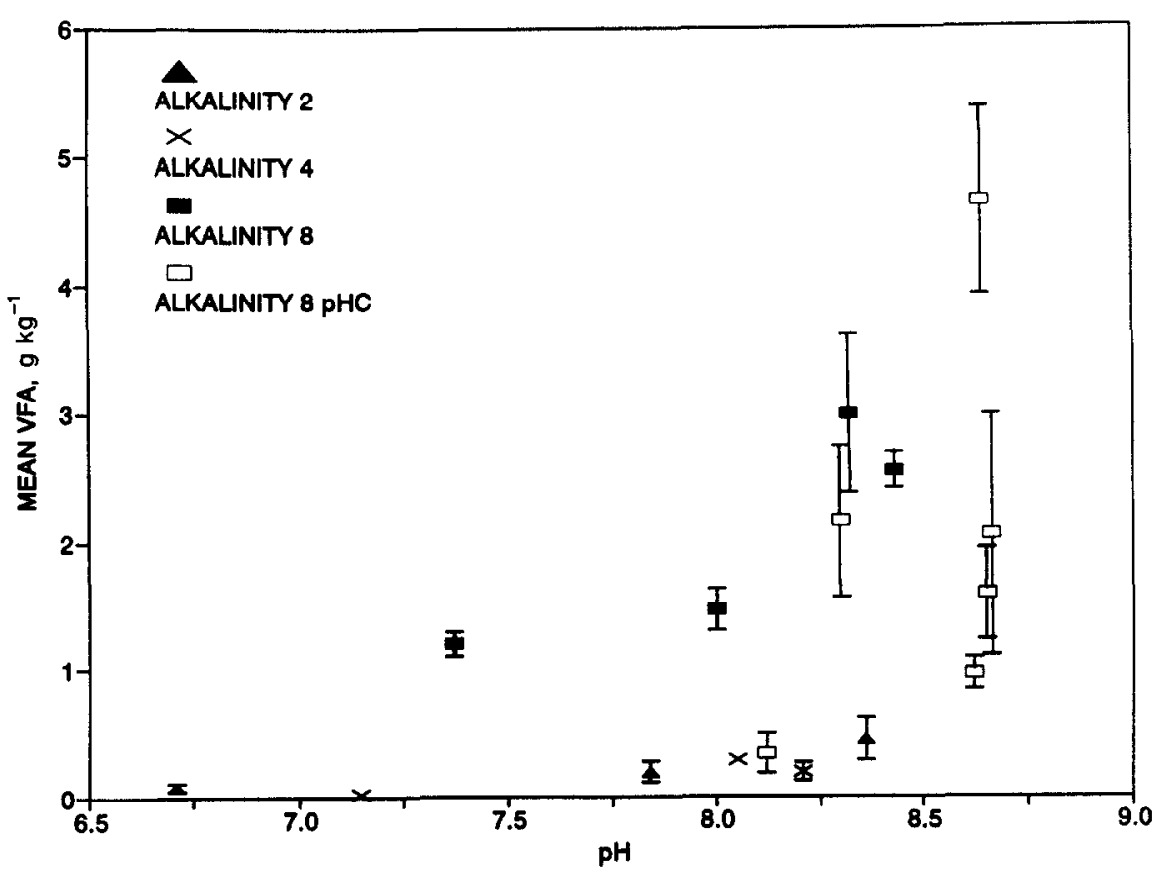

Fig. 7. Relationship of the mean digester $\mathrm{pH}$ to digester VFA concentrations $\left(\mathrm{g} \mathrm{kg}^{-1}\right.$ as $\mathrm{C} 2$ ).

become excessive, as at elevated $\mathrm{pH}$ the relative concentration of the free $\mathrm{NH}_{3}$ form increases, which may cause toxicity ${ }^{12}$ at levels greater than $100 \mathrm{mg} \mathrm{l}^{-1}$.

Larger-scale testing will be necessary to determine practical designs and operating requirements for in situ methane enrichment. Initial pilot-scale testing of methane enrichment was carried out at the Experimental Test Unit in Florida. ${ }^{13}$

Acknowledgements - This research was carried out at Cornell University supported by the Gas Research Institute under GRI Contract No. 5088-260-1658, Dr Thomas D. Hayes, GRI project manager. The co-authors especially recognize Frederick Herndon's persistent operation of the experimental systems for 3 years. The contributions of Timothy D. Nock, Kent B. Bares, Elizabeth M. Flow, Dr Ho Kang, Craig O. Thomas and Karl Lindenaur are gratefully acknowledged.

\section{REFERENCES}

I. R. Legrand, T. M. Masters, C. S. Warren and T. D. Hayes, Analysis of biological gasification of terrestrial biomass using the ECSA model. In D. L. Klass (Ed.), Energy from Biomass and Waste XII. Institute for Gas Technology, Chicago, IL (1988).

2. J. R. Frank and W. H. Smith, Perspectives on biomass research. In W. H. Smith and J. R. Frank (Eds), Methane from Biomass: A Systems Approach. Elsevier Applied Science, London (1987).

3. J. F. Ferguson, B. J. Eis and M. M. Benjamin, Neutralization in anaerobic treatment of an acidic waste. Water Res. 18(5), 573-580 (1984).

4. T. D. Hayes and H. R. Isaacson, Bioengineering concepts for methane enrichment in anaerobic digestion, pp. 496-510. In Proceedings of the 1984 International Gas Research Conference, Chicago, IL (1984).
5. T. D. Hayes, H. R. Isaacson, J. T. Pfeffer and Y. M. Liu, In situ methane enrichment in anaerobic digestion. Biotechnology and Bioengineering 35, $73-86$ (1990).

6. W. J. Jewell, H. Kang, F. G. Herndon, B. K. Richards and T. E. Whitc, Engineering design considerations for methane fermentation of energy crops. Cornell University Annual Report, Fourth Year, for the Gas Research Institute, Report Number GRI-88/0263, Chicago, IL (January 1988).

7. W. J. Jewell, R. J. Cummings, B. K. Richards, F. G. Herndon, T. E. White, C. C. Nicholson, W. A. Chrusciel and K. G. Lindenauer, Engineering design considerations for methane fermentation of energy crops-fundamental considerations. Cornell University Annual Report, First Year, for the Gas Research Institute Report Number GRI-91/0010, Chicago, IL (December 1989).

8. W. J. Jewell, R. J. Cummings, F. G. Herndon, T. D. Nock, B. K. Richards, T. E. White, W. Chrusciel and C. C. Nicholson, Engineering design considerations for methane fermentation of energy crops-fundamental considerations. Cornell University Annual Report, Second Year, for the Gas Research Institute, Report Number GRI-91/0275, Chicago, IL (September 1991).

9. B. K. Richards, R. J. Cummings and W. J. Jewell, High rate low solids anaerobic methane fermentation of sorghum, corn and cellulose. Biomass and Bioenergy 1 , 249-260 (1991).

10. B. K. Richards, R. J. Cummings, W. J. Jewell and T. E. White, Methods for kinetic analysis of methane fermentation in high solids biomass digesters. Biomass and Bioenergy 1, 65-73 (1991).

11. P. L. McCarty, Anaerobic waste treatment fundamentals: part 2: environmental requirements and control. Public Works 123-126 (October 1964).

12. G. Parkin and W. F. Owen, Fundamentals of anaerobic digestion of wastewater sludges. ASCE-JEED $112(5)$, $867-920$ (1986)

13. V. Srivastava and A. Hill, Methane Enrichment Digestion Experiments at the Anaerobic Experimental Test Unit at Walt Disney World. Insitute for Gas Technology Annual Report for the Gas Research Insitute, Report No. GRI-92/0498 (June 1993). 